\section{ESPUTOS DE PAPEL. LA HISTORIETA 'UNDERGROUND' ESPAÑOLA}

\author{
Pablo Dopico \\ Doctor en Historia del Arte
}

\section{PAPER 'SPUTUM'. THE SPANISH UNDERGROUND CARTOON}

RESUMEN: Para conocer el origen y desarrollo de la historieta española contemporánea, debemos adentrarnos en los suburbios de la cultura visual. Así descubriremos la historia del cómic underground español. Un cómic donde, gracias a la relativa libertad de expresión que ofrecía, la contracultura encontró un vehículo versátil con el que podía expresarse sin trabas, convirtiéndose en una nueva forma de protesta y reivindicación social que ofreció un impagable testimonio de la realidad española, superior al que ofrecen otras artes coetáneas. El artículo analiza las principales características, aspectos estéticos y novedades lingüísticas del comix español, descubriendo sus principales autores (Ceesepe, Gallardo, Mariscal, Max y Nazario), series (Makoki, Los Garriris, Gustavo, Anarcoma,...) y revistas (El Rrollo Enmascarado, Star, La Piraña Divina, Butifarra!, Los Tebeos del Rrollo, Rock Comix, EI Vibora,...), y mostrando su conexión con otras artes, como la pintura, el cine y la fotografía, sin olvidarnos de su relación con el mundo de las drogas y la música rock.

PALABRAS CLAVE: Underground comic; comix marginal; contracultura; cultura visual; El Rrollo; El Vibora.

KEY WORDS: Underground comic; commix marginal; counterculture; visual culture; El Rrollo; El Víbora.

Para conocer el origen y desarrollo de la historieta española contemporánea, debemos adentrarnos en los suburbios de la cultura visual para descubrir la historia del cómic underground español, también llamado cómic contracultural, marginal, subterráneo o comix (terminado en $\mathrm{x}$ ). Analizaremos sus principales características, aspectos estéticos, sus novedades lingüísticas, sus principales autores, series y revistas, y su conexión con otras artes, como la pintura, el cine y la fotografía, sin olvidarnos de su relación con el mundo de las drogas y la música rock.

El movimiento underground ${ }^{1}$ nació en los campus universitarios de EE UU en los años sesenta. Con un espíritu inconformista, un grupo de jóvenes y filósofos desencantados con el modo de vida americano expresó su deseo de crear una cultura nueva al margen de la oficial. Sus orígenes se remontan a las protestas de la beat generation estadounidense, el sentimiento trágico de la nueva filosofía francesa y el fenómeno hippie, que, con una nueva sensibilidad pacífica, enarbolaba la bandera de la liberación individual, el amor libre y la revolución psicodélica.

El comix underground nació ligado a la prensa contracultural que desarrollaron estos jóvenes inconformistas. Un cómic que podemos definir literalmente como "subterráneo", si utilizamos el termino anglosajón que lo sitúa "bajo lo establecido", pero que también puede entenderse como marginal y alternativo. Gracias a la relativa libertad de expresión que ofrecía, la contracultura encontró en el cómic un vehículo versátil con el que podía expresarse sin trabas de ningún tipo, convirtiéndose en una nueva forma de protesta y reivindicación social. Su espíritu transgresor atravesó las fronteras y llegó a Europa y, unos años más tarde, ya en la década de los setenta, a España, donde estas publicaciones asombraron a una juventud rebelde que no dudó en copiarlas, creando modelos propios que después utilizaron como armas contra la dictadura franquista y la sociedad que deseaban cambiar.

Desde entonces, en apenas cuarenta años, la población española ha vivido enormes cambios en todos los ámbitos de la sociedad, incluido en el mundo de la historieta. Se han implantado nuevas artes que reivindican un nuevo 
placer estético fundamentado en la ironía, el exceso, la distorsión, la crítica y la complicidad con el espectador, que buscan la belleza donde el buen gusto establecido determina que no la hay. Una belleza alejada de cánones, proporciones y armonías, que se sitúa en los abismos del sistema. Nuevos antihéroes callejeros, ácratas y de dudosa moral, como Anarcoma, Gustavo, Slober, Fermín y Piker, derrotaron y sustituyeron a los héroes tradicionales del cómic español como el Capitán Trueno, el Guerrero del Antifaz, Cuto, Roberto Alcázar y Pedrín, que encarnaban los ideales y valores oficiales del pasado. Seres de papel que se convirtieron en los nuevos iconos de una juventud descontenta con la realidad que les había tocado vivir, que tenía enormes ganas de comunicarse, de gritar y de cambiar el mundo. Jóvenes inquietos y creativos que utilizaron el cómic como medio de expresión y difusión de sus ideas contrarias al sistema.

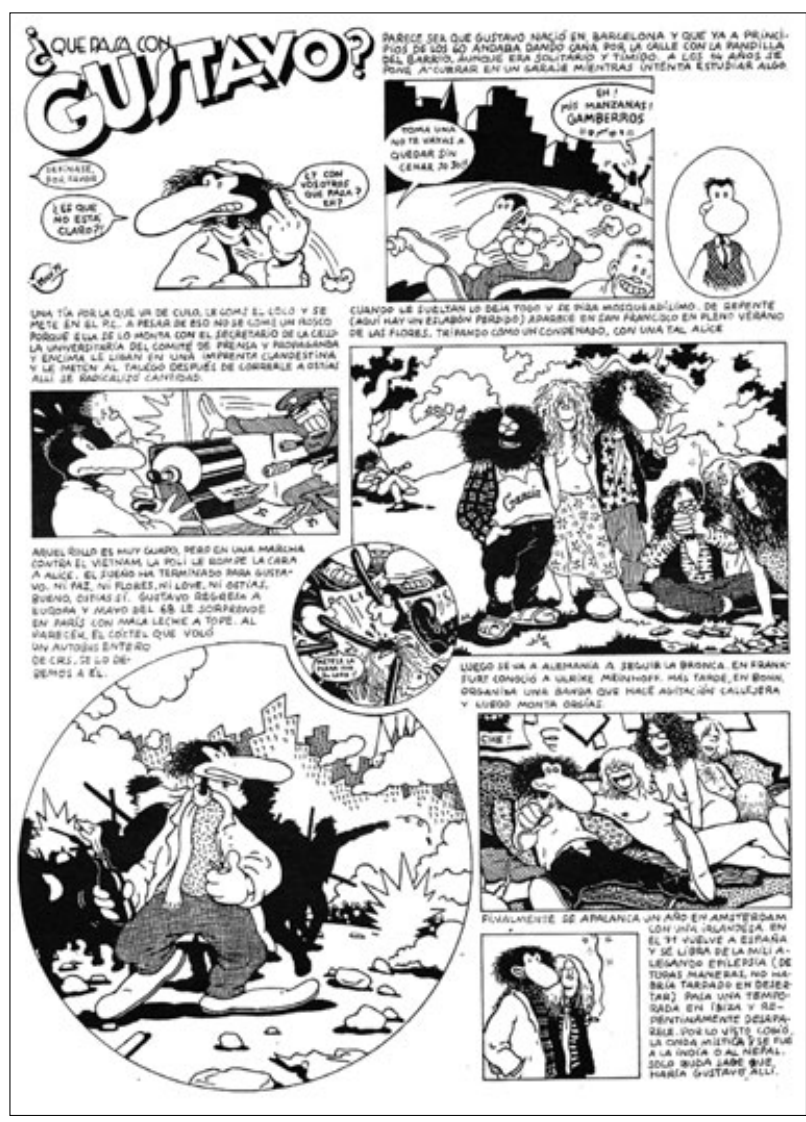

Imagen 1. Max, "Gustavo contra la actividad del radio", en El Víbora $n^{0} 1$, Barcelona 1979.

\section{CómO CREAR ENTRE LA CLANDESTINIDAD Y LA REPRESIÓN}

Entre 1970 y 1975 encontramos las primeras creaciones artísticas del cómic underground español. En los censores y dictatoriales primeros años de la década llegaron a España, clandestinamente, aires de libertad procedentes de otros países, como ilustró Max en las primeras páginas de "Gustavo contra la actividad del radio" (imagen 1). La juventud descubría el alcohol, las drogas y el rock and roll y una creciente politización flotaba en el ambiente. Pero, desgraciadamente, muchos jóvenes de esta "generación bífida"2 vivieron tan deprisa que se quedaron en el camino.

En estos años se desarrollaron en España diversos movimientos de oposición al régimen franquista. Un espíritu contestatario se introducía lenta pero paulatinamente en la sociedad española, que sufría la mordaza de unas estrictas normas de censura. Barcelona era la ciudad más cosmopolita, abierta a las tendencias vanguardistas de la cultura y la contestación sociopolítica. Las playas de Ibiza y Formentera, el Rastro madrileño y las Ramblas barcelonesas se convertían en centros de reunión de hippies y grupos juveniles automarginados que formaban parte del naciente underground ibérico.

Estos movimientos creativos también afectaron al mundo de los tebeos, que para marcar distancias respecto a las historietas destinadas al público infantil, comenzaban a llamarse cómics, emulando la nueva corriente del cómic adulto europeo. Este acercamiento intelectual al mundo de la historieta promovió la revisión y el estudio de sus contenidos, formas expresivas, obras y autores clásicos, reivindicando el cómic como manifestación cultural popular digna de entrar en los museos. Sus creaciones dejaban de ser concebida como un producto de entretenimiento infantil y juvenil para transformarse en un prestigioso producto de autor con nuevas posibilidades artísticas aún por explorar.

Junto a estos primeros balbuceos, la editorial Fundamentos publicó en abril de 1972 la primera antología del comix contracultural estadounidense, titulada Comix Underground USA, cuya portada recuperaba la de aquel $\mathrm{n} 00$ de Zap Comix, de Robert Crumb. Este tebeo con formato de libro recopilaba algunas obras de Crumb, Victor M oscoso y Gilbert Shelton, que fueron convenientemente retocadas y redibujadas para evitar problemas con la censura vigente. Sus páginas abrieron el horizonte a muchos jóvenes dibujantes españoles, 
convirtiéndose en su libro de estilo e influyendo en el desarrollo de su obra gráfica posterior.

Sobre esta base floreciente nació el verdadero movimiento del cómic underground español. En septiembre de 1973, tras varios meses de incubación, El Rrollo Enmascarado 3 (imagen 2) brotó igual que un forúnculo en las Ramblas barcelonesas. Era la primera publicación underground del equipo de dibujantes de El Rrollo, integrado por Nazario, $M$ ariscal y los hermanos Miguel y J osep Farriol, a los que se unieron Guillermo, Francesc Capdevilla (que más tarde se daría a conocer bajo el pseudónimo de Max), Antonio Pàmies, Roger e Isa. Este fue el embrión de un grupo de artistas y dibujantes vanguardistas que presentaba unas inquietudes creativas diferentes a las establecidas, que creció y desarrolló su obra utilizando la historieta como medio de expresión, creando uno de los estilos más importantes e innovadores

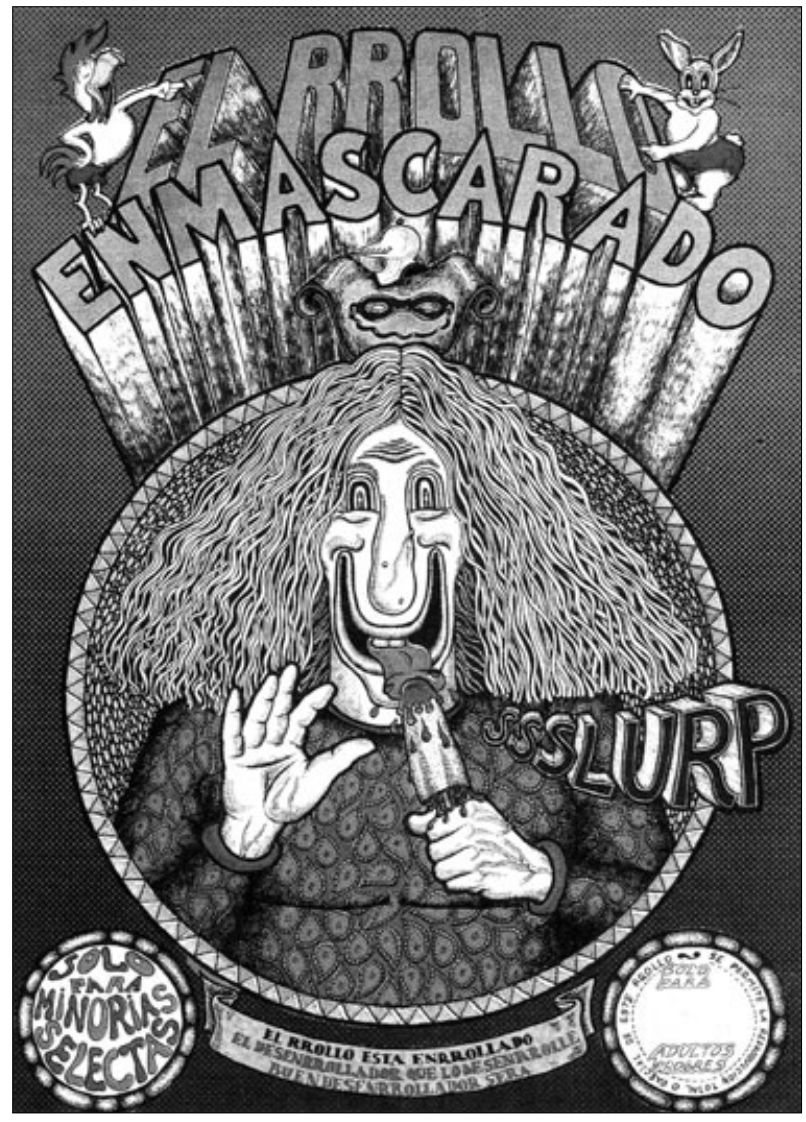

Imagen 2. Josep Farriol, portada de El Rrollo Enmascarado, Barcelona, 1973. de nuestro cómic, renovando y marcando las pautas del tebeo español contemporáneo.

Tras conseguir el dinero necesario y encontrar un impresor que se atreviera a imprimir su revista, lanzaron una tirada de 1.000 ejemplares, declarando oficialmente solo 300 para no llamar la atención de las autoridades. Pero, a los pocos días de hacer el obligatorio depósito previo del tebeo ante el Ministerio de Información y Turismo, las autoridades procedieron al secuestro de la publicación al ser considerada como atentatoria contra la moral pública. Sobre su autor, Miguel Farriol Vidal, pesaban cargos por supuesto escándalo público, por lo que el Ministerio Fiscal pidió una pena de seis meses de arresto mayor, 15.000 pesetas de multa y nueve años de inhabilitación especial. Nueve meses después, en mayo de 1974, la Audiencia Provincial de Barcelona absolvió al autor y editor de El Rrollo Enmascarado, autorizando su libre difusión. Sin pérdida de tiempo, el equipo de El Rrollo comenzó a venderlo por las Ramblas, mercadillos y bares de Barcelona frecuentados por la progresía de la época, buscando el contacto directo con el público lector.

Tras el éxito alcanzado, en junio de 1974, los componentes de El Rrollo publicaron dos nuevas revistas, Catalina, que también fue sometida a juicio de faltas y condenada a pagar una multa de 4.000 pesetas; y Pauperrimus Comix, que sufrió la autocensura de sus autores, con vistas a su publicación como separata del no 56 de la revista Nueva Dimensión. A finales de año lanzaron Diploma D'Honor, un tebeo musical que ilustraba las canciones de la emergente estrella de la música catalana Jaume Sisa; De Quommic, que presentaron en la sala Zeleste de Barcelona; y, ya en 1975, la editorial Mandrágora publicó el álbum Purita.

Javier M ariscal, regresó a Valencia para realizar el servicio militar, y mientras servía a su poco amada patria dibujó $A$ Valènciaa, su primer tebeo unitario, que autoeditó en 1975 bajo el sello de El Rrollo. En su interior incluía la historia "Un Diumenge Pel Matí", donde ofrecía su irónica y particular visión de Valencia, denunciaba la destrucción de la ciudad por el progreso e insinuaba su preocupación por los temas ecológicos. Mariscal presentaba la capital del Turia habitada por sus principales edificios, que adquieren un peculiar aspecto antropomórfico y protagonizan acciones cotidianas que dan pie a narraciones gráficas costumbristas de gran detallismo. 
Mientras tanto, nacía Star (1974-1980), una publicación decisiva para el desarrollo de la cultura marginal española. Fundada por Juan J osé Fernández y M ontesol, bajo el amparo de Producciones Editoriales, Star fue concebida como una revista de comix y prensa marginal que, durante seis años y 57 números, presentó al público español una muestra del cómic underground internacional junto a las creaciones de los nuevos dibujantes marginales españoles. Mediante un soporte estable y relativamente profesional, pretendía acoger las tendencias innovadoras de aquella época, cumpliendo una importante función cultural al poner en contacto a sus lectores con formas de expresión contraculturales desconocidas en España, cometido que logró siempre que las multas y los secuestros se lo permitieron.

Sus primeros números pasaron inadvertidos, tanto para las autoridades como para gran parte del público, hasta que el

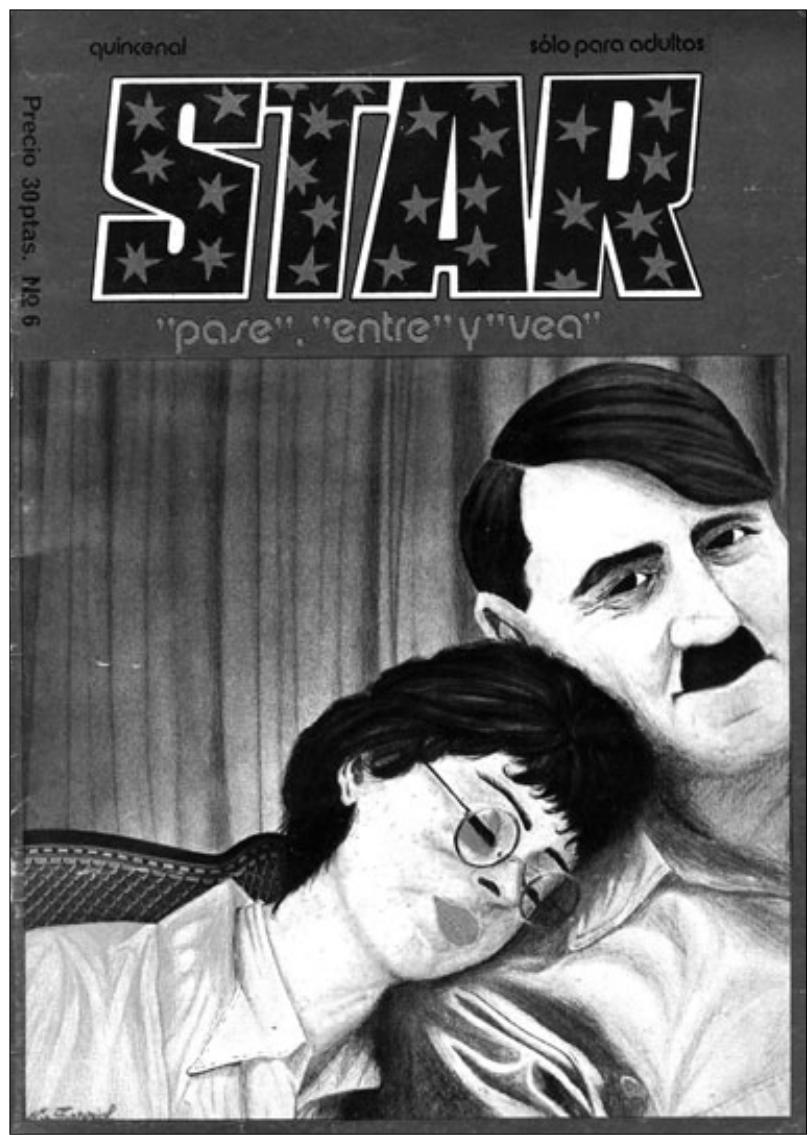

Imagen 3. Miguel Farriol, portada de Star $n^{\circ} 6$, Barcelona, 1974. no 6 (imagen 3), que presentaba en su portada una ilustración de Hitler en actitud hogareña, realizada a todo color por Miguel Farriol, inauguró los problemas con la censura con una falta grave, un expediente y una multa de 100.000 pesetas. El no 7 también fue expedientado por una infracción muy grave y la multa fue de 150.000 pesetas. El fatídico no 13, dedicado al gato Fritz, de Robert Crumb, fue secuestrado por las autoridades, animadas por la denuncia de un padre de familia despistado, que compró a su hijo una revista "solo para adultos", pensando que las aventuras de este gato revoltoso eran unos inocuos dibujos de Walt Disney. Cuando Star celebraba su primer aniversario, sufrió un nuevo expediente por el $n-15$, lo que provocó el cierre temporal de la revista en julio de 1975.

En su interior, Star conjugaba la publicación de historietas realizadas por autores españoles conocidos, como Ceesepe, M ontesol, El Hortelano, Pepe López, Nazario y Max, con otras obras de escasa calidad realizadas por dibujantes noveles. La temática y la técnica de estas obras continuaban la línea de ruptura respecto a los gustos establecidos que habían iniciado los integrantes de EI Rrollo. Esto suponía el triunfo de la estética del "mal gusto", que incorporaba el lenguaje vulgar de la calle y mostraba una visión cruda de sexo, violencia y drogas protagonizada por los nuevos arquetipos que florecían en la sociedad española, formados por modernos antihéroes, hippies, pasotas, progres y melenudos.

La situación parecía increíble, hasta que en mayo de 1975 Nazario autoeditó La Piraña Divina. Las páginas de este fanzine clandestino agrupaban todo el material que el autor sevillano no podía publicar en las revistas de la época ni presentar a censura previa porque no la pasaría de ninguna manera. Y no se equivocaba, ya que el azar quiso que la policía encontrara un ejemplar en la primera edición del festival musical "Canet Rock". Este tebeo colmó la paciencia de la Administración, que tachó la obra de pornográfica y trató de localizar a su anónimo autor. Pero, ¿qué tenía de especial La Piraña Divina para escandalizar de esta manera a las autoridades? Una cantidad de sexo explícito tratado con un sarcasmo y una ironía como no se había visto antes en las páginas del comix español, lo que suponía la transgresión de uno de los tabúes más sagrados de la sociedad española. La virginidad femenina, la virilidad masculina, la abstinencia sexual y la situación del homosexual en aquellos años eran caricaturizados en unas historietas que recurrían a la ridiculización de situaciones típicas y tópicas, la exageración expresiva y la transposición temporal. 
En sus páginas destacaba la historia "Tentación, Martirio y Triunfo de San Reprimonio, Virgen y Mártir" (imagen 4), en la que Nazario desarrolló una parodia contemporánea de las tentaciones de San Antonio, jugando con el nombre del santo y la utilización del desfasado lenguaje religioso del "bien" y el lenguaje popular y vulgar del "mal". Los préstamos de la iconografía cristiana son evidentes y la tentación homosexual se manifiesta en el combate maniqueo entre Dios y el Diablo. Nazario se supera a sí mismo y ofrece un magnífico ejemplo de la finalidad subversiva del comix underground, que, armado con pluma y papel, lucha contra la inanidad de los tradicionales valores eternos e inmutables de la sociedad franquista.
Imagen 4. Nazario, "Tentación, martirio y triunfo de San Reprimonio, virgen y mártir", en La Piraña Divina, Barcelona,

1975 .

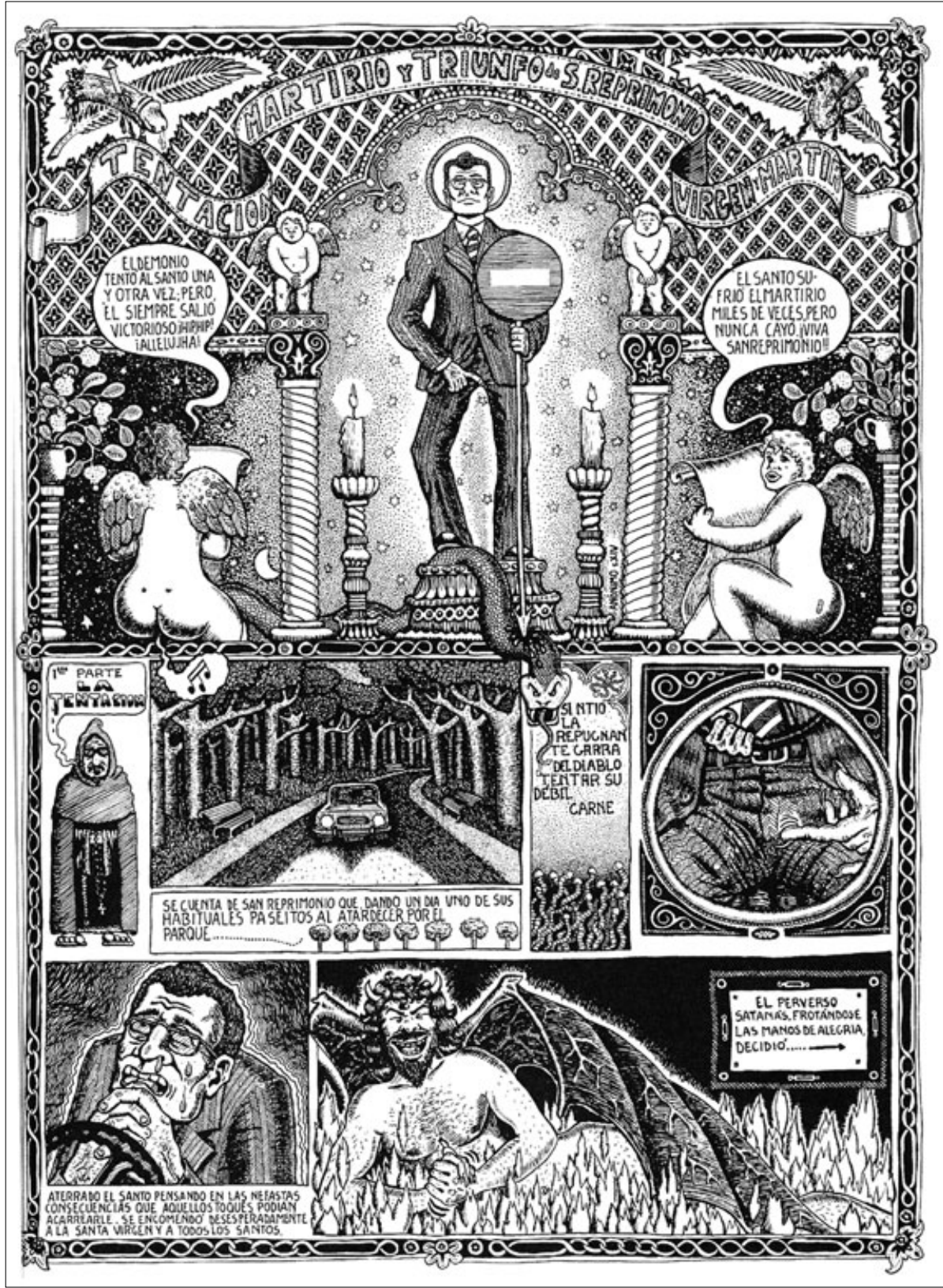

ARBOR CLXXXVII 2EXTRA 2011 169-181 ISSN: 0210-1963

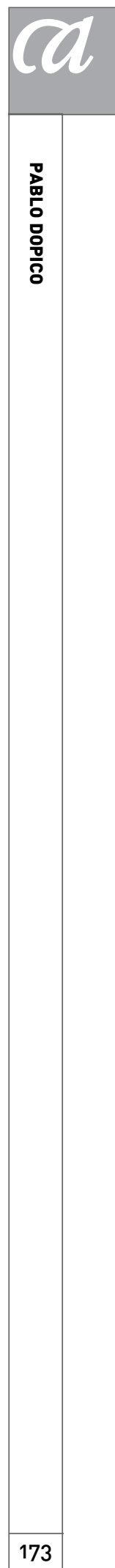


Tras el escándalo y después de varios meses de represión contra estas emergentes publicaciones contraculturales, los acontecimientos políticos que anunciaban el final de la dictadura parecían clarificarse en el horizonte. Una nueva tolerancia censora parecía aceptar imágenes y temáticas que antes eran duramente reprimidas. Los marginados salían de sus refugios para adoptar una postura crítica en su lucha contra el sistema. El deseo de cambio animaba a gran parte de la juventud a buscar nuevos estilos de vida, nuevas músicas, nuevas publicaciones marginales y nuevos comix que parecían renacer con nuevos proyectos de la gente de El Rrollo, la revista Vibraciones, el emergente equipo Pastanaga, el colectivo Butifarra!, los madrileños de Carajillo y la deseada vuelta de Star y Ajoblanco.

Sus historietas se dirigían hacia un público joven, convirtiéndose en el portavoz y medio de expresión de una juventud descontenta, heredera en parte de una ideología hippie y pacifista, con tendencias políticas de izquierda, que vivía ahogada y frustrada por la represión franquista. Con gran ingenio y un humor ácido y reflexivo, entre la sátira y la ironía, estos autores se convirtieron en testigos irrespetuosos y blasfemos que plasmaban las cosas que veían y expresaban lo que sentían a través de unos dibujos de aspecto sucio y recargado que no buscaban la belleza. Recurrieron a los tópicos del underground, formados por el triángulo temático del sexo, la violencia y las drogas, que encontró otro vértice en la música rock, todo ello mezclado con una gran variedad de vivencias y frustraciones personales. De esta forma, criticaron los valores tradicionales y los tabúes más sagrados de la sociedad española, como la patria, la religión, la familia, el sexo y el Ejército.

Gráficamente, presentaban una estética nueva para una sociedad nueva. Desarrollaron nuevas posibilidades expresivas mediante el feísmo, la audacia en el tratamiento de planos y la interrelación con otras artes. La imagen predomina sobre los textos; las tramas y rayados manuales llenan la página, realzando la sensación de profundidad y el volumen de las figuras; juegan con la forma de las viñetas; la perspectiva y la variación de planos es continua, saltando del plano general, que muestra numerosos detalles del escenario donde transcurre la acción, al primer plano, para mostrar unos rostros desbordantes de expresividad. También recurren al uso de visuales onomatopeyas, líneas de velocidad, imágenes secuenciales dobles y elementos gráficos que sustituyen a los textos, todo ello dibujado con un detallismo minucioso de gran realismo.

\section{DesarRollo del 'COMIX' esPañol}

Tras la muerte de Franco, el país avanzaba hacia la democracia, se iniciaba la reconciliación nacional y se vivía un nuevo espíritu liberal. Una corriente de "hippismo tardío" parecía impregnar el espíritu de una nueva generación de españoles que no compartía la lucha política de sus hermanos mayores. Muchos pensaron ingenuamente que por fin se resolverían todos los problemas de sus vidas y que serían más felices. Pero fueron víctimas de un espejismo y la esperanzadora alegría del cambio pronto dejó paso a la frustrante perplejidad del desencanto. Un desencanto que dio lugar al pasotismo, la apatía y la indiferencia de muchos jóvenes ante una sociedad que no ofrecía suficientes estímulos vitales para ellos.

Con la desaparición del franquismo y el relajamiento de la censura, se hacía factible el desarrollo de una historieta adulta en forma y contenidos. Entre 1976 y 1979 se produce el crecimiento y desarrollo del comix español, en unos años de efervescencia política y creativa que vieron nacer numerosas revistas y fanzines underground. Paralelamente, los aspectos teóricos y literarios de la contracultura eran tratados por revistas ácratas como Ajoblanco, EI Viejo Topo y Ozono, y libros publicados por editoriales como Anagrama, Tusquets, Visor y Fundamentos.

Entre las revistas de estos años destaca Butifarra!, expresión catalana equivalente a un corte de mangas, que tras sus inicios en Hospitalet como modesto panfleto vecinal de combate, se convirtió en la revista de cómic comprometida por antonomasia. Inmersa en los sueños de concienciación y participación popular que lideraban las asociaciones de vecinos de aquella época, sus historietas plasmaban en imágenes la problemática de los barrios y las preocupaciones del pueblo y la clase trabajadora. Sus autores utilizaron el cómic como medio informativo independiente y desarrollaron el valor de la historieta como instrumento ideológico.

Otras publicaciones fueron Nasti de Plasti; los tres números de la colección Los Tebeos del Rollo, titulados Carajillo Vacilón, El Sidecar y A la Calle; y Picadura Selecta, un grueso tebeo editado por Iniciativas Editoriales en octubre de 1976. En su interior destacaba por su extensión y calidad gráfica y narrativa la elaborada historia "Don Pixôt de l'Eixampla" (imagen 5), de Antonio Pàmies. Una peculiar versión de El Quijote, políticamente incorrecta, protagonizada 
Imagen 5. Antoni Pàmies, "Don Pixot de l'Eixampla", en Picadura Selecta, Barcelona, 1976.
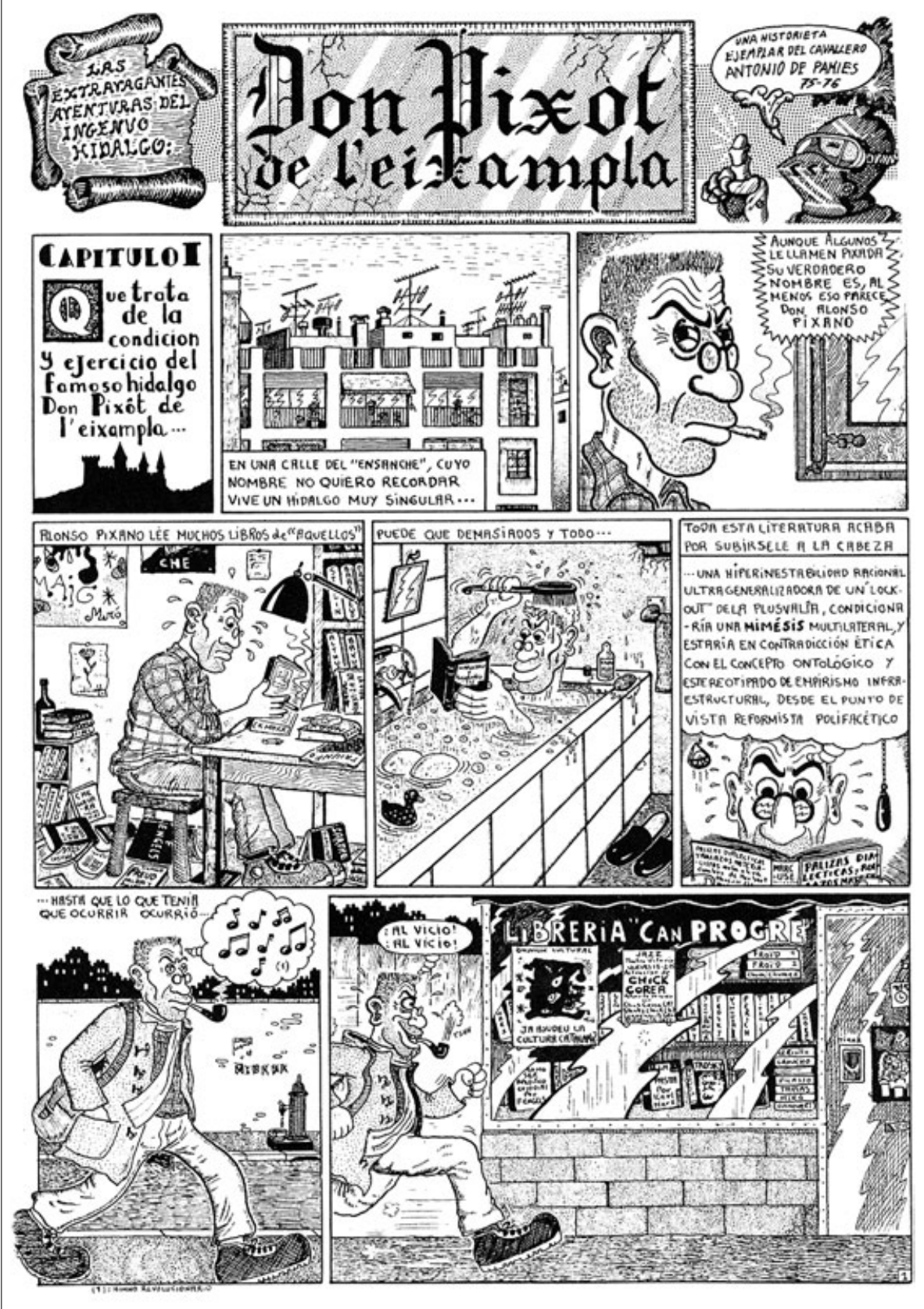

por un hidalgo catalán del siglo XX, marxista, revolucionario e idealista, que en sus utópicas aventuras chocaba una y otra vez con la triste realidad social del país. En general, la historia sigue la línea argumental de la obra de Cervantes, pero desde un punto de vista contemporáneo, en el que la parodia a los libros de caballería se convierte en una sátira de la literatura política y revolucionaria y una crítica ácida y mordaz de la sociedad española de los años setenta. Pàmies utilizó su estilo caricaturesco habitual, a medio camino entre el comix underground estadounidense y el cómic humorístico español del TBO y la Escuela Bruguera. 
Por otro lado, en junio de 1976 Star regresó a los quioscos para celebrar su segundo aniversario con la esperanza de que nada ni nadie se iba a oponer a su misión informativa y que los nuevos tiempos iban a ser propicios para quienes trataban de escapar del conformismo de la cultura oficial. Pero su alegría duró poco y los problemas con las autoridades continuaron durante la transición democrática, ya que los no 16 y 24 (abril de 1977) también fueron secuestrados. En esta segunda etapa la revista adquiere un aspecto más profesional y desarrolla un grafismo más moderno y amable, adaptado a los nuevos tiempos. Sus Ilamativas portadas mostraban las últimas tendencias gráficas que llegaban al país, con influencias estéticas muy diversas, procedentes del collage y el pop art. Aunque el comix español pierde espacio frente a la historieta foránea, Star publicó algunas joyas como "Vicios modernos" (imagen 6), una obra de tintes postmodernos en la que Ceesepe mostraba la cara menos amable de Madrid y descubría su relación con la fotografía, al realizar sus dibujos a partir de instantáneas de

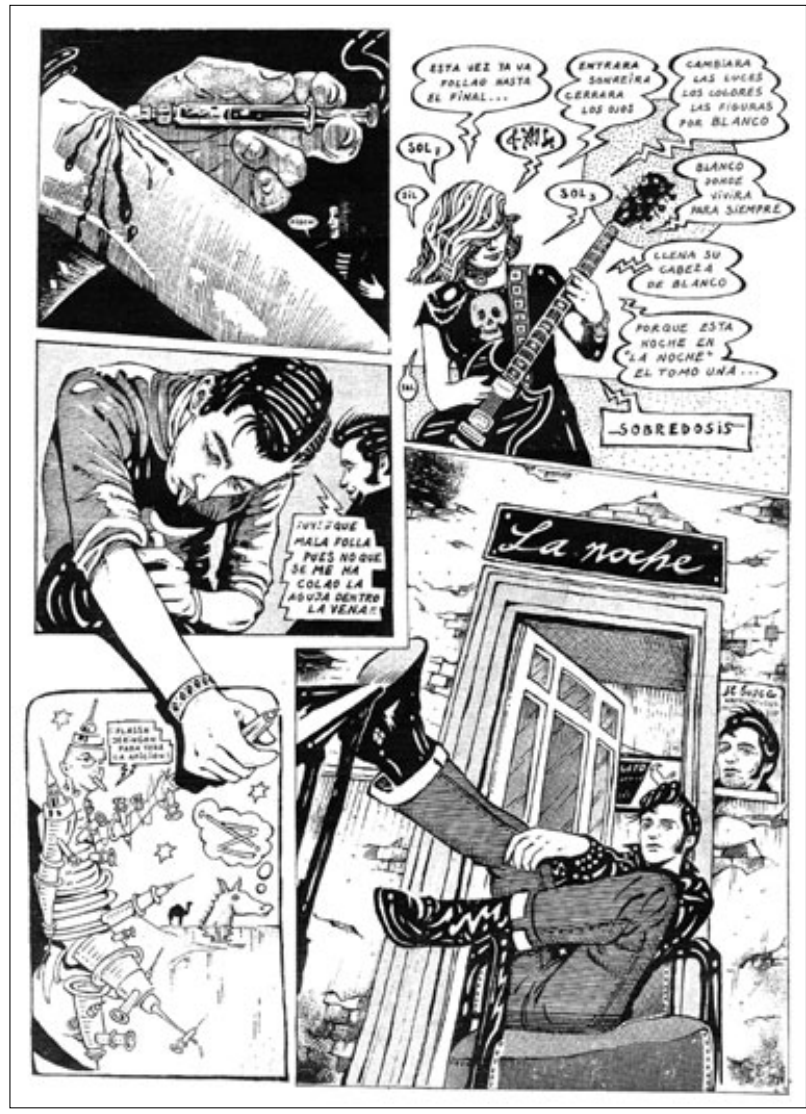

Imagen 6. Ceesepe, "Vicios modernos", en Star nº 38, Barcelona, 1978.
Alberto García Alix, la Cochu, Vicky y Ouka Lele. La historia entremezcla los tópicos de las drogas, el sexo y el rock'n'roll, con un dibujo de estilo hiperrealista de línea clara y trazo sencillo, de gran expresividad y dinamismo, lleno de referencias y guiños al lector cómplice que también vivía al límite.

Como se puede comprobar, son muchas las afinidades y paralelismos existentes entre el comix y la música rock4. Los dibujantes de comix encontraron en el rock un espejo donde mirarse y un vivero de ideas donde desarrollar argumentos e historias protagonizadas por las emergentes tribus musicales. Buena parte de la prensa marginal española se movía a su ritmo, reflejando su estética, pelos largos y forma de vida. Surgieron numerosas revistas que fusionaron magistralmente las notas musicales con la tinta china y el papel, como $L a$ cara oculta de Monkey Billy, en la que Ceesepe rendía homenaje a los Rolling Stones; Ademuz Km 6, autoeditado por Sento y Micharmut, con motivo del primer festival de música rock que se celebró en esa localidad valenciana; y Rock Comix (1976), que publicó interesantes monografías sobre los rockeros más importantes del momento.

Pero, no solo de cómics vive el hombre, como demuestra la ilustración de portadas de discos, que se convirtió en un pequeño reducto gráfico y una importante fuente de ingresos para algunos dibujantes del comix español. En 1983 Gallardo y M ediavilla ilustraron la portada del EP de Paraíso Makoki. Años más tarde, Gallardo realizó en solitario la colorista portada del disco de Los Rebeldes Esto es rocanrol. Ceesepe ilustró las portadas del EP de Golpes Bajos Malos tiempos para la lírica, Seré mecánico por ti, de Kiko Veneno, y el primer álbum de Ketama. El Hortelano realizó una portada chulesca y castiza para el exitoso álbum de Gabinete Caligari Al calor del amor en un bar... El alejamiento de algunos creadores del mundo del cómic, en busca de nuevos campos de expresión económicamente más rentables, como la ilustración y el diseño, ya era una realidad.

En esos años los comix se extendieron por todos los rincones del país, convirtiéndose en un medio de comunicación portador de un mensaje liberador y un instrumento de concienciación que posibilitó el análisis y la crítica de la realidad del momento. Eran años de clandestinidad tolerada que permitían la aparición de numerosos fanzines realizados por artistas y dibujantes que editaban sus propias revistas de manera casi artesanal. Fanzines formados por un puñado de páginas que eran fotocopiadas, grapadas y dobladas por el propio 
dibujante, que, a la vez, era quien las vendía en la calle a un público nuevo que demandaba un nuevo tipo de historietas. Como ejemplo de este fenómeno, citaremos la prensa marginal realizada en Madrid5, que todavía sufría las consecuencias de cuarenta años de intensa dictadura y frustrante represión. Sus fanzines ofrecían una mentalidad propia de la contracultura española, de tintes ácratas y nihilistas, bañada por una enorme desconfianza hacia todo lo que representaba el poder. Esta subcultura comenzó a manifestarse en diferentes núcleos de la capital, como algunas facultades de la Universidad Complutense, el Rastro y el Ateneo Politécnico del barrio de Prosperidad, que sirvió de foco de distintas actividades culturales independientes y catalizador de la prensa marginal madrileña a través de PREMAMA, una activa asociación que quería crear nuevos medios de comunicación al margen de la prensa oficial. Las revistas que integraron PREM AMA reflejaron su interés por abordar nuevas temáticas y por la experimentación creativa, con títulos como Acera, El Alucinio, Catacumba, Schmurz, Uronia, Agra, El Cadáver de Mandrágora, Cerrus, MMM! y Bazofia.

Muchos españoles comenzaron a perder el miedo a la policía, a los vecinos, al ridículo y a uno mismo, y empezaron a vivir libremente, produciéndose una ruptura radical con el pasado. Frente a la pana, el pelo largo, las barbas rizadas y la canción protesta, se imponían el destape, el porro, el rock'n'roll y el deseo de disfrutar de la vida nocturna, el entretenimiento y la diversión. El nuevo alcalde de Madrid, Enrique Tierno Galván, impulsó la creatividad y la agitación cultural en un movimiento sin precedentes que empezó como una imitación de la nueva ola londinense y desembocó en la llamada "movida madrileña". Nuevos artistas, como Alberto García Álix, Pablo Pérez Mínguez, Ouka Lele, Eduardo Haro Ibars, Pedro Almodóvar, Kiko Feria, Fabio de Miguel, Alaska, el Zurdo, las Costus y Ceesepe, despuntaron con sus ideas vanguardistas y crearon una mitología gráfica provocadora que mostraba un nuevo espíritu de transgresión. Camino de la postmodernidad, Madrid se convirtió en la capital lúdica de la diversión y la experimentación cultural española.

\section{ACEPTACIÓN DEL 'COMIX' ESPAÑOL}

Con la llegada de los democráticos ochenta la historieta española inició un periodo de expansión y una época dorada, abandonando el gueto infantil donde había permanecido arrinconada desde los años del franquismo para desarrollar una novedosa historieta para adultos, un nuevo concepto de cómic de autor y adquirir una nueva e importante consideración entre el gran público.

Progresivamente, se produce la aceptación del cómic underground español, que, en busca de la profesionalización de sus principales autores, alcanzó unos niveles artísticos inimaginables y pasó a formar parte de la industria del cómic español, al producirse su aceptación social y su explotación comercial. El comix supo adaptarse a los nuevos tiempos, alcanzando su cota más elevada gracias a la revista EI Vibora y a Cobi, un personaje de Los Garriris, creado por Mariscal, que, sin darse cuenta, se convirtió en la mascota de los J uegos Olímpicos de Barcelona de 1992.

Sus autores crearon nuevas historias que se oponían, satirizaban y atacaban el sistema establecido con temáticas inéditas, protagonizadas por personajes de la calle que plasmaban sus problemáticas cotidianas. La historieta underground abandona la clandestinidad para alcanzar una mayor difusión y popularidad entre los lectores, como demuestra el éxito de Makoki6 (imagen 7), que nació en junio de 1977 en la revista musical Disco-Express, de la mano de Gallardo, Mediavilla y Borrallo. Símbolo de una época caótica e icono de la llamada línea chunga, se convirtió en uno de los personajes emblemáticos de la contracultura española. Tras escapar de un manicomio, camisa de fuerza incluida, este loco de cables chispeantes y mirada enrabietada vivió numerosas aventuras en las que mostraba los bajos fondos de aquella España. Sus calles, bares, gentes, lenguaje callejero y argot lumpen se desparramaban entre parodias e historias costumbristas poco convencionales. El éxito de Makoki provocó que su imagen apareciera estampada en camisetas, cartas y tarjetas postales, protagonizó varios álbumes, tuvo una revista propia, recibió numerosos homenajes, se convirtió en tema de alguna exposición, y hasta Fernando Márquez "El Zurdo" le dedicó una canción.

El comix español reflejaba en sus abigarradas viñetas la temática de la contracultura, lo alternativo y todo aquello que estaba al margen de la oficialidad. En el país, ni el cine, ni la literatura, ni la pintura, habían dado tanta importancia a lo que pasaba en la calle, y fue la historieta la primera en dirigir su mirada hacia esta nueva temática urbana marginal, donde encontró imágenes impactantes, ocultas entre lo ordinario y la realidad cotidiana, que despertaron 
nuevas inquietudes entre los lectores. En la actualidad, estas obras se han convertido en documentos gráficos de excepcional interés que ofrecen un reflejo histórico de los acontecimientos ocurridos en España en aquella época.

Muchos habían sido los cambios registrados en España desde que Star lanzara su primer número, aunque estos no habían sido los cambios soñados por los más utópicos. En su última etapa, Star disminuyó el número de páginas dedicadas al comix nacional, y hasta las portadas, que antes reproducían dibujos e ilustraciones, adquieren un aspecto más moderno, adaptándose a los nuevos tiempos con las fotografías de Ouka Lele, Jordi García y Montse Camping. Pero, a pesar de los cambios, el no 57 (abril de 1980) fue el último de Star y su desaparición dejó un gran vacío en la prensa marginal española.

Bésame Mucho (1980-1983) recogió el testigo y buscó una nueva línea editorial a través de contenidos, temáticas y una estética diferentes, adaptadas a los nuevos tiempos. Inmersa en la curiosidad y la experimentación formal de los años ochenta, esta revista se convirtió en la cantera de

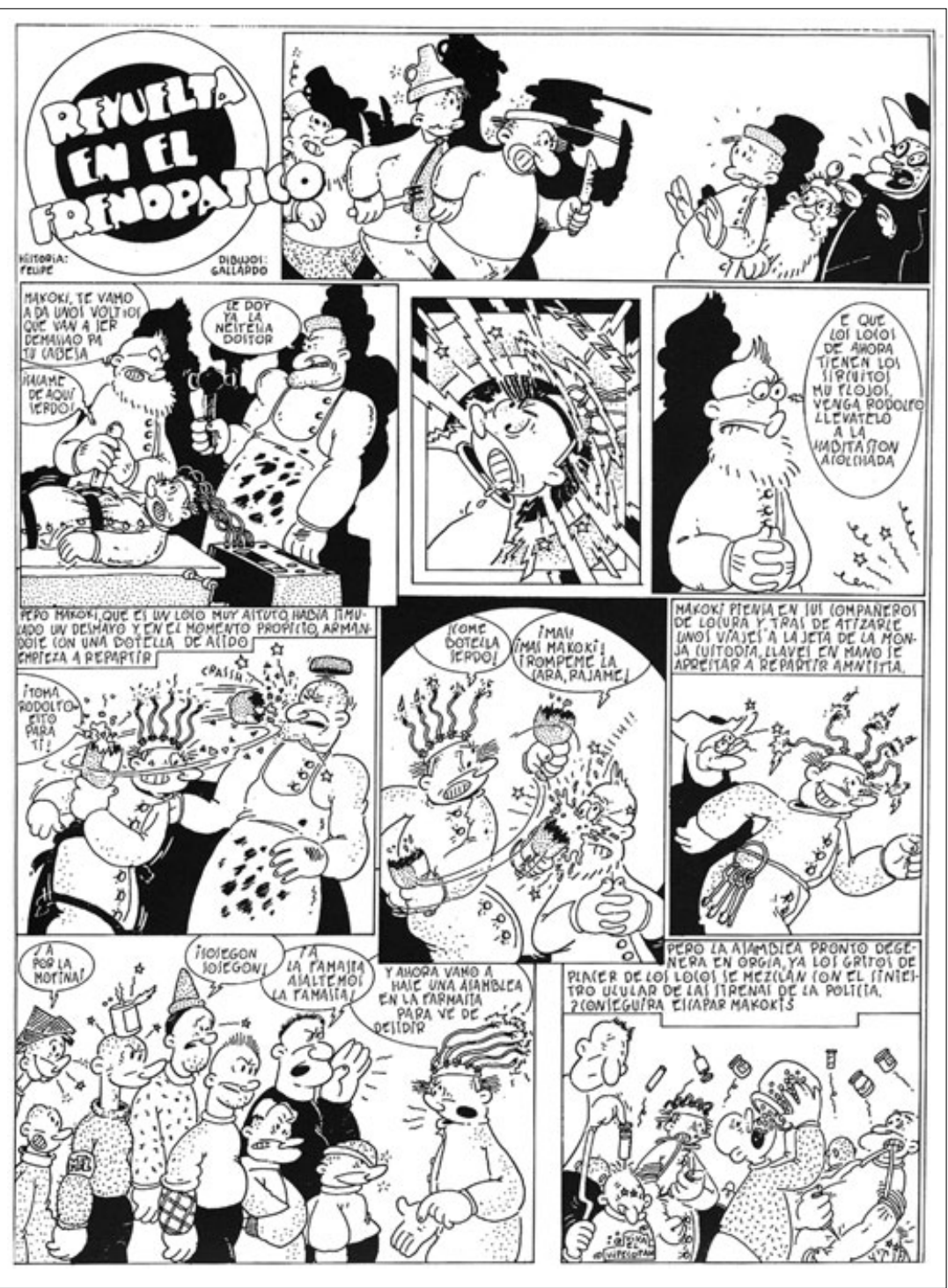

Imagen 7. Gallardo y Borrallo, "Revuelta en el frenopático", en Disco-Exprés $n^{\circ} 432$, Barcelona, 1977 . 
jóvenes autores españoles en vías de profesionalización, que tras su desaparición, acabarían publicando su obra en las páginas de Cairo. En total fueron 30 números de gran calidad gráfica que cerraron la travesía editorial de Juan José Fernández, que así ponía fin a un ciclo vital dedicado a la difusión de la contracultura en nuestro país. Inevitablemente, algo había cambiado en la sociedad española durante estos años: la ilusión había dejado paso al escepticismo, los pelos cortos y la alopecia acababan con las frondosas melenas y la modernidad se abría paso entre la progresía española.

Con este panorama de fondo, el comix underground español encontró su mejor soporte donde sobrevivir en la revista El Vibora (1979-2004) (imagen 8). Fundada en diciembre de 1979 por Josep María Berenguer, con el apoyo de J osep Toutain, su creación dio lugar al nacimiento de la editorial La Cúpula. Las páginas de EI Víbora descubrieron una nueva forma de entender los comix, caminando por el lado más oscuro de la marginalidad con unas posturas adultas que admitían la experimentación gráfica y narrativa en sus viñetas. Lo underground dejó de difundirse solo por medios subterráneos, y su consolidación comercial y la profesionalización de sus autores se hacía realidad.

En sus páginas se asentó una generación de dibujantes curtida en numerosos fanzines y revistas marginales, que hicieron de la crítica social y las nuevas actitudes de rebeldía su seña de identidad, reflejando como nadie el lado más salvaje y canalla de la España democrática de los ochenta. Nazario, que por derecho propio se había convertido en el medidor de la tolerancia receptiva del público y las autoridades frente al comix, publicó a todo color las aventuras de Anarcoma, el detective transexual y ramblero más famoso del mundo del cómic. Con un estilo propio de gran calidad gráfica, años antes de recibir el Premio Nacional de Cómic7, Max publicó las aventuras de "Gustavo contra la actividad del Radio" (imagen 1), protagonizadas por un personaje caricaturesco y antropomórfico que representaba la conciencia social, combativa y radical de la contracultura española. Gustavo es un progre español cualquiera, desilusionado con el pasado y reconvertido en un activista luchador ecologista y antinuclear. Un reflejo de aquellos supervivientes que continuaban luchando contra el sistema. Otros autores como Gallardo y Mediavilla, Alfredo Pons, Martí, Daniel Torres, Roger, Montesol, Sento, Pámies y Simónides, también publicaron sus obras en las páginas de EI Víbora, lo que confirmaba el espíritu de la revista, abierta a las nuevas generaciones de dibujantes y las corrientes estéticas alternativas, que no tenían que ser provocadoras ni provocativas.

El comix demostraba que no era una simple moda pasajera fácil de emular y que, aunque repetía los manidos esquemas del underground, permanecía ajeno a la crítica y ofrecía un enfoque desenfadado y absurdo que había rebajando sus aspectos más agresivos. El periodo inicial de asentamiento de la revista se vio reforzado por el intento de golpe de Estado de Tejero, el 23 de febrero de 1981, contra el que sacaron un número especial en el que manifestaron una postura radical que sorprendió a muchos. Este número representó una especie de reconocimiento político de la publicación, que se puso de moda y se convirtió en un símbolo de modernidad entre muchos jóvenes, que, poco a poco, olvidaban la dictadura franquista. El Vibora sobrepasó los cauces habituales del mercado del cómic español y se convirtió en la revista más vendida de los quioscos españoles. Entre 1982 y

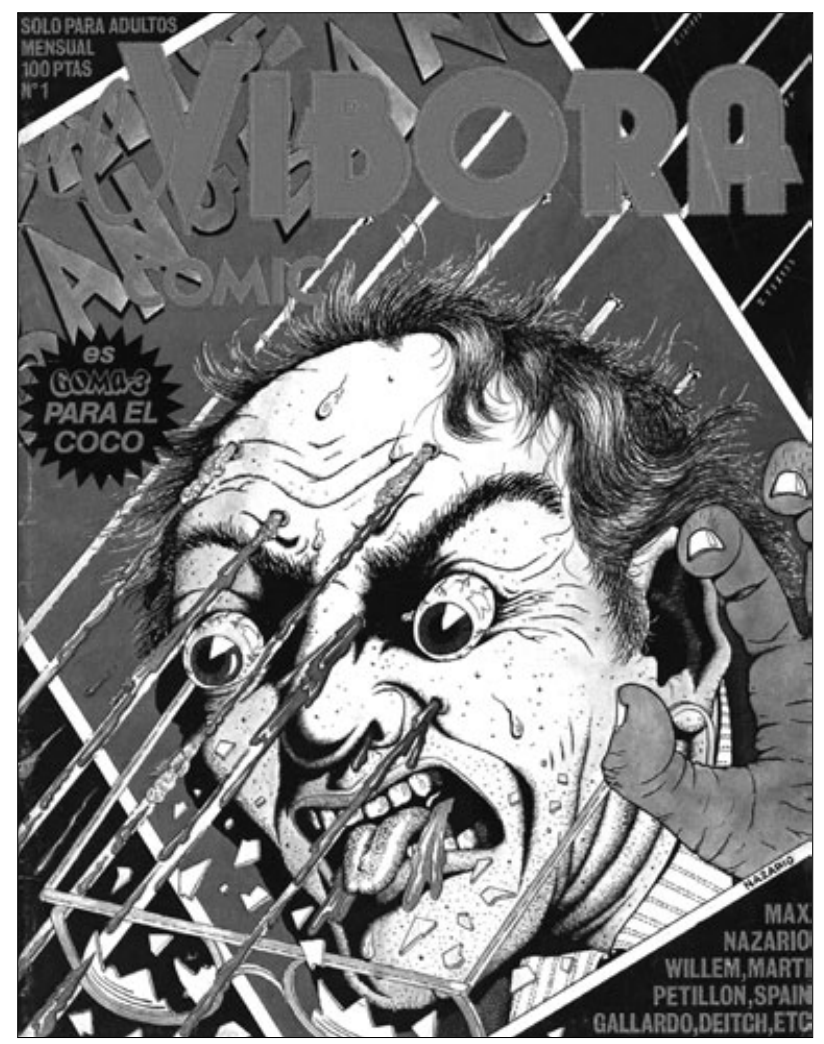

Imagen 8: Nazario, portada de El Víbora $n^{\circ}$ 1, Barcelona, 1979. 
1983, alcanzó unas cifras de ventas que oscilaban entre los 40.000 y los 50.000 ejemplares mensuales, algo inimaginable por los pioneros del comix marginal español. Además, debido a su condición colectiva y gregaria, este número de compradores generaba un número aún mayor de lectores, que podía superar la cifra de 500.000 personas.

El Vibora se erigió en estandarte de la evolución cultural española y su éxito inusitado se convirtió en un fenómeno social difícil de explicar. La revista había aglutinado una serie de autores y lectores, que, con el paso de los años fue cambiando; pero también evolucionó, aunque fue perdiendo parte del veneno que arrojaba cada mes, adaptándose a las nuevas posturas del país, más tolerantes e individualistas, y las nuevas estéticas, más experimentales e iconoclastas. A pesar de todo, El Víbora publicó su último número, el 300 , en diciembre de 2004, tras 25 años de historia en el cómic español. Durante este cuarto de siglo El Víbora se convirtió en un importante icono y símbolo de la historieta española que ha contribuido a normalizar el cómic adulto en la industria editorial del país.

Mientras tanto, la lista de fanzines continuó creciendo, con la grata novedad de que muchos adquirieron elevados niveles de calidad, llenando sus páginas de ingenio e imaginación. La crítica a los valores imperantes, la escenificación de la rebelión más radical, la exhibición explícita del sexo, la identificación con las últimas tendencias pictóricas y los guiños a la fotografía y el cine se hacen patentes en sus viñetas. Muchos han suavizado sus contenidos y su estilo gráfico, en un intento de acercarse a un mayor número de lectores, pero otros han radicalizado aún más sus temáticas, al pensar que en estos momentos también hay muchas causas contra las que luchar.

Finalmente, la cultura vigente ha asimilado el movimiento contracultural, y la historieta underground ha pasado a formar parte del sistema a través de la moda, el lenguaje y el mimetismo formal. El cómic underground se ha convertido en cómic alternativo. Se ha producido un cambio generacional y han surgido nuevas actitudes e inquietudes vitales que necesitan nuevos medios de expresión. Nuevos sentimientos que hacen que muchos símbolos de la modernidad, el pasotismo y la progresía del pasado queden desfasados y desbordados por una frenética actividad a medio camino entre la estética punk y el virtuosismo gráfico, la modernidad y el tono cutre y provocador.

Hoy son pocos los dibujantes underground 0 alternativos que pueden subsistir exclusivamente del noveno arte, y artistas como Max, Miguel Ángel Martín, Javier Olivares, Mauro Entrialgo, Álvarez Rabo, Paco Alcázar, Miguel Brieva y Ladrón, se han convertido en una especie en extinción que cada vez dilata más la aparición de sus nuevas historietas, mientras dirigen sus creatividad hacia otras actividades artísticas económicamente más rentables. A pesar de todo, la marginalidad que les ofrece el cómic permite que estos autores gocen de más libertad creativa que en otros medios de expresión para continuar ofreciendo un impagable testimonio de la realidad española contemporánea, superior al que ofrecen otras artes coetáneas.

\section{NOTAS}

1 Sobre la contracultura y el movimiento underground véase: Roszak, Theodore, El nacimiento de una contracultura. Kairós, Barcelona, 1978; Maffi, Mario, La Cultura Underground. Anagrama, Barcelona, 1975; De Villena, Luis Antonio, La revolución cultural. Planeta, Barcelona, 1975; Racionero, Luis, Filosofias del underground. Anagrama, Barcelona, 1977.

2 Haro Tecglen, Eduardo, "La generación bífida", en El País, 27 de noviembre de 1988. Citado en Benito Fernández, J.,
Eduardo Haro lbars: los pasos del caído. Anagrama, Barcelona, 2005, 383.

3 Sobre el El Rrollo Enmascarado véanse: Vigil, Vigil, "Cómo nace un Rrollo", en El Rrollo. Producciones Editoriales, Barcelona, 1975, 3-6; Martín, Antonio, "Nacimiento y primeros pasos de El Rrollo Enmascarado", en www.tebeosfera.com, octubre de 2004; Dopico, Pablo y Carrillo, Jesús, "El Rrollo", en Desacuerdos 3. Sobre arte, políticas y esfera pública en el Estado Español. Arteleku, MACBA, UNIA, Barcelona, 2005, 186-193; y Dopico, Pablo, El cómic underground
Recibido: 30 de septiembre de 2010
Aceptado: 1 de diciembre de 2010 
español, 1970-1980. Cátedra, Madrid, 2005, 48-66.

4 Sobre la conexión entre comix y rock véase: Puchades, Juan, Cómic y Rock. Midons, Valencia, 1995; y Dopico, Pablo, El cómic underground español, 1970-1980, op. cit., 20-247.

5 Sobre la prensa marginal madrileña, véase: Babas, Kike y Turrón, Kike, De espaldas al kiosko. Guía histórica de fanzines y otros papelujos de

\section{BIBLIOGRAFÍA}

Altarriba, Antonio (2001): España del tebeo. La historieta española de 1940 a 2000. Madrid: Espasa-Calpe.

BABAS, Kike y Turrón, Kike (1996): De espaldas al kiosco. Guía histórica de fanzines y otros papelujos de alcantarilla. Madrid: El Europeo \& La Tripulación.

Benito Fernández, J. (2005): Eduardo Haro Ibars: los pasos del caído. Barcelona: Anagrama.

Cervera, Rafa (2002): Alaska y otras historias de la movida. Barcelona: Plaza $\&$ Janes.

Conde Martín (2003): "¿Qué fue del comix underground?", en Revista Cultural de Ávila, Segovia y Salamanca, $\mathrm{n} 042,43$ y 44, enero-marzo.

Cuadrado, J. (2000): De la historieta y su uso, 1873-000. Atlas español de la cultura popular. 2 vols., Madrid: Ediciones Sinsentido y Fundación Germán Sánchez Ruipérez.

DE VILENA, Luis Antonio (1975): La revolución cultural. Barcelona: Editorial Planeta. alcantarilla. El Europeo \& La Tripulación, Madrid, 1996, 46-47; González, Julián, "Antecedentes de la prensa marginal", en Ajoblanco, Extra Prensa Marginal, 1978, 14-18; Dopico, Pablo y Carrillo, Jesús, "Bazofia y la prensa marginal madrileña", en Desacuerdos 3, op. cit., 209-213; Dopico, Pablo, El cómic underground español, 1970-1980, op. cit., 247-272.

DopICo, Pablo (2005): El cómic underground español, 1970-1980. Madrid: Cátedra.

Equipo en PunTa (1976-1977): "Prensa marginal al poder", en En Punta, no 23 y 24.

LLAdó PoL, Francesca (2001): Los cómics de la transición. (El boom del cómic adulto 1975-1984). Barcelona: Glénat.

MAfFl, Mario (1975): La Cultura Underground. 2 vols., Barcelona: Editorial Anagrama (1a ed., Roma, 1972).

Puchades, Juan (1995): Cómic y Rock. Valencia: Midons Editorial.

Racionero, Luis (1977): Filosofías del underground. Barcelona: Anagrama.

RIBAS, José (2007): Los 70 a destajo. Ajoblanco y libertad. Barcelona: RBA.

RoszAK, Theodore (1978): El nacimiento de una contracultura. Barcelona: Editorial Cairos (1a ed. 1970).

SABIN, Roger (1996): Comics, Comix \&t Graphic Novels. A History of Comic Art. Londres: Phaidon Press.

VIGIL, Luis (1975): "Cómo nace un Rro\|lo", en El Rrollo. Barcelona: El Rrollo, Producciones Editoriales, 3-6.
6 Sobre Makoki véase: Makoki integral. Glénat, Barcelona, 2002; Altarriba, Antonio, La España del tebeo. La Historieta española de 1940 a 2000. Espasaalpe, Madrid, 2000, 351-365; y Dopico, Pablo, El cómic underground español, 1970-1980, op. cit., 360-369.

7 Max recibió el Premio Nacional de Cómic en 2007 por Hechos, dichos, ocurrencias y andanzas de Bardín el Superrealista.

VILAROS, Teresa M. (1998): El mono del desencanto. Una crítica cultural de la transición española (1973-1993). Madrid: Siglo XXI.

VV AA (1971): "Los cómics", en Estudios de Información, no 19-20, julio-diciembre, Madrid: Secretaría General Técnica del Ministerio de Información y Turismo.

- (1976): El comix marginal español. Álbum especial Star Book, Barcelona: Producciones Editoriales.

- (1978): "Prensa Marginal", en Ajoblanco, Lacochu (coord.), no extra, octubre, Barcelona: Ajoblanco Ediciones.

- (2001): San Nazario y las Pirañas Incorruptas. Obra completa de $\mathrm{Na}$ zario de 1970 a 1980. Barcelona: Ediciones La Cúpula.

- (2002): Makoki integral. Barcelona: Glénat.

- (2006): Desacuerdos 3. Sobre arte, políticas y esfera pública en el Estado Español. Barcelona: Arteleku, MACBA y UNIA. 